\title{
Editorial: Circadian Control of Immunity
}

\author{
Koichi lkuta $^{1 *}$ and Christoph Scheiermann ${ }^{2,3,4 *}$ \\ ${ }^{1}$ Laboratory of Immune Regulation, Institute for Frontier Life and Medical Sciences, Kyoto University, Kyoto, Japan, \\ 2 Department of Pathology and Immunology, Faculty of Medicine, University of Geneva, Geneva, Switzerland, ${ }^{3}$ Biomedical \\ Center, Faculty of Medicine, Institute of Cardiovascular Physiology and Pathophysiology, Ludwig Maximilians University, \\ Planegg-Martinsried, Germany, ${ }^{4}$ Walter-Brendel-Centre of Experimental Medicine, University Hospital, Ludwig Maximilians \\ University, Munich, Germany
}

Keywords: circadian immunity, innate immunity, adaptive immunity, leukocyte migration, control of circadian immunity

Editorial on the Research Topic

Circadian Control of Immunity

\section{OPEN ACCESS}

Edited and reviewed by: Francesca Granucci, University of Milano-Bicocca, Italy

${ }^{*}$ Correspondence: Koichi lkuta

ikuta.koichi.6c@kyoto-u.ac.jp

Christoph Scheiermann christoph.scheiermann@unige.ch

Specialty section:

This article was submitted to

Molecular Innate Immunity, a section of the journal

Frontiers in Immunology

Received: 18 October 2020

Accepted: 22 October 2020

Published: 30 November 2020

Citation:

Ikuta $K$ and Scheiermann $C$ (2020) Editorial: Circadian Control of Immunity.

Front. Immunol. 11:618843. doi: 10.3389/fimmu.2020.618843

\section{INTRODUCTION}

The circadian clock influences virtually every aspect of life in mammals. Circadian clocks allow the organism to adjust to and anticipate recurring changes in their rhythmic environment, allowing for a better fitness and survival $(1,2)$. Within the immune system, it has long been known that the organism's response to immune stimulation is highly time-of-day dependent, resulting in overactivation and even death (3). Thus, while the existence of an overall oscillation in the response to an immune stimulant over $24 \mathrm{~h}$ has been recognized decades ago, the molecular mechanisms behind these features remained elusive until recently. In this special issue, we highlight the recent developments in the fast-growing field of circadian immunology.

Historically, the influence of the circadian clock on the innate system has been recognized first and thus this is the aspect of circadian immunology that we know most about so far. This is also due to the fact that time-of-day was thought to exert its influence most strongly on the acute effect of the immune system. More recent data, however, demonstrate that also the adaptive immune system is clock-controlled, although also here previous observations had already indicated an impact of timeof-day (4). This review series focuses on the recent developments in the circadian aspects of immune cell functions, providing an overview over the innate and adaptive immune system, neuronal and hormonal control as well as the influence of the microbiome on rhythmic immunity.

One of the most prominent features of a rhythmic immune system is the rhythmic fluctuation of immune cells in blood. Recent data indicate that this reflects their redistribution from blood to tissues, which is reviewed by Yuan et al. Thus, the temporal difference in the presence of certain immune cells at specific sites in blood and tissues will certainly contribute to any differences in the immune response. 


\section{RHYTHMS IN THE INNATE AND ADAPTIVE IMMUNE SYSTEM}

The cell type that so far has been investigated in most detail is the macrophage $(5,6)$. Timmons et al. provide an in-depth overview over the recent developments with respect to their time-of-day dependency. Neutrophils, the most abundant immune cells in human blood, have remained a much less-studied leukocyte subset but have also been shown to be highly rhythmic in their activity and their trafficking patterns $(7,8)$. Aroca-Crevillén et al. provide an overview into the recent scientific developments in this aspect. Pourcet and Duez give insights into the rhythmic activation of the inflammasome, a key inflammatory signalling complex that integrates inflammatory input with immune cell output (9). In addition, the adaptive immune system is highly rhythmic and this has been demonstrated in detail with respect to allergic reactions. Nakao sums up the recent data into the role of the circadian clock in allergy.

\section{NEURAL AND HORMONAL CONTROL}

An important question that is currently an active field of research is how immune cells and immune responses in general are entrained. Recent data indicate that both glucocorticoids (10) as well as the sympathetic nervous system $(11,12)$ can govern these oscillations. Leach and Suzuki as well as Shimba and Ikuta discuss these recent developments with respect to adrenergic nerves as well as glucocorticoids, respectively. Interestingly, these oscillations are not only affecting mature leukocyte populations but are also observed at the level of hematopoietic stem and progenitor cells (13). García-García and Mendez-Ferrer discuss the recent development in the field with respect to immature hematopoietic cell populations.

\section{REFERENCES}

1. Ouyang Y, Andersson CR, Kondo T, Golden SS, Johnson CH. Resonating circadian clocks enhance fitness in cyanobacteria. Proc Natl Acad Sci USA (1998) 95(15):8660-4. doi: 10.1073/pnas.95.15.8660

2. Spoelstra K, Wikelski M, Daan S, Loudon AS, Hau M. Natural selection against a circadian clock gene mutation in mice. Proc Natl Acad Sci USA (2016) 113(3):686-91. doi: 10.1073/pnas.1516442113

3. Halberg F, Johnson EA, Brown BW, Bittner JJ. Susceptibility rhythm to E. coli endotoxin and bioassay. Proc Soc Exp Biol Med (1960) 103:142-4. doi: 10.3181/00379727-103-25439

4. Fernandes G, Halberg F, Yunis EJ, Good RA. Circadian rhythmic plaqueforming cell response of spleens from mice immunized with SRBC. J Immunol (1976) 117(3):962-6.

5. Gibbs JE, Blaikley J, Beesley S, Matthews L, Simpson KD, Boyce SH, et al. The nuclear receptor $\mathrm{REV}-\mathrm{ERB} \alpha$ mediates circadian regulation of innate immunity through selective regulation of inflammatory cytokines. Proc Natl Acad Sci USA (2012) 109(2):582-7. doi: 10.1073/pnas.1106750109

6. Keller M, Mazuch J, Abraham U, Eom GD, Herzog ED, Volk HD, et al. A circadian clock in macrophages controls inflammatory immune responses. Proc Natl Acad Sci USA (2009) 106(50):21407-12. doi: 10.1073/pnas. 0906361106

7. Adrover JM, Del Fresno C, Crainiciuc G, Cuartero MII, Casanova-Acebes M, Weiss LA, et al. A Neutrophil Timer Coordinates Immune Defense and

\section{MICROBIOTA}

While the field is currently trying to better understand how a complex, multicellular organism orchestrates rhythmic immune reactions, the level of complexity is increased even further by the role that exogenous factors, predominantly the commensal microbiota, play in this. Aspects of the gut microbiota have been shown to be strongly rhythmic (14) and Butler and Gibbs, as well as Kubo sum up the recent insight into this role.

\section{CONCLUSIONS}

The circadian control of immunity is achieved in a cell autonomous manner by clock genes and can be entrained with the help of adrenergic nerves and glucocorticoids. This collection of review articles on the Research Topic "Circadian Control of Immunity" provides the latest and comprehensive update in this rapidly growing field of immunology research.

\section{AUTHOR CONTRIBUTIONS}

Both authors contributed equally to the manuscript. All authors contributed to the article and approved the submitted version.

\section{FUNDING}

Work in KI's lab is supported by the Japan Society for the Promotion of Science (JSPS) KAKENHI Grant Numbers $20 \mathrm{~K} 21525$ and $18 \mathrm{~K} 15184$. Work in CS's lab is supported by the Swiss National Science Foundation (SNF, 310030_182417).

Vascular Protection. Immunity (2019) 50(2):390-402.e10. doi: 10.1016/ j.immuni.2019.01.002

8. Gibbs J, Ince L, Matthews L, Mei J, Bell T, Yang N, et al. An epithelial circadian clock controls pulmonary inflammation and glucocorticoid action. Nat Med (2014) 20(8):919-26. doi: 10.1038/nm.3599

9. Pourcet B, Zecchin M, Ferri L, Beauchamp J, Sitaula S, Billon C, et al. Nuclear Receptor Subfamily 1 Group D Member 1 Regulates Circadian Activity of NLRP3 Inflammasome to Reduce the Severity of Fulminant Hepatitis in Mice. Gastroenterology (2018) 154(5):1449-1464.e20. doi: 10.1053/ j.gastro.2017.12.019

10. Shimba A, Cui G, Tani-Ichi S, Ogawa M, Abe S, Okazaki F, et al. Glucocorticoids Drive Diurnal Oscillations in T Cell Distribution and Responses by Inducing Interleukin-7 Receptor and CXCR4. Immunity (2018) 48(2):286-298.e6. doi: 10.1016/j.immuni.2018.01.004

11. Suzuki K, Hayano Y, Nakai A, Furuta F, Noda M. Adrenergic control of the adaptive immune response by diurnal lymphocyte recirculation through lymph nodes. J Exp Med (2016) 213(12):2567-74. doi: 10.1084/ jem.20160723

12. Scheiermann C, Kunisaki Y, Lucas D, Chow A, Jang JE, Zhang D, et al. Adrenergic nerves govern circadian leukocyte recruitment to tissues. Immunity (2012) 37(2):290-301. doi: 10.1016/j.immuni.2012.05.021

13. Méndez-Ferrer S, Lucas D, Battista M, Frenette PS. Haematopoietic stem cell release is regulated by circadian oscillations. Nature (2008) 452(7186):442-7. doi: $10.1038 /$ nature 06685 
14. Thaiss CA, Zeevi D, Levy M, Zilberman-Schapira G, Suez J, Tengeler AC, et al. Transkingdom control of microbiota diurnal oscillations promotes metabolic homeostasis. Cell (2014) 159(3):514-29. doi: 10.1016/j.cell.2014.09.048

Conflict of Interest: The authors declare that the research was conducted in the absence of any commercial or financial relationships that could be construed as a potential conflict of interest.
Copyright $\odot 2020$ Ikuta and Scheiermann. This is an open-access article distributed under the terms of the Creative Commons Attribution License (CC BY). The use, distribution or reproduction in other forums is permitted, provided the original author $(s)$ and the copyright owner(s) are credited and that the original publication in this journal is cited, in accordance with accepted academic practice. No use, distribution or reproduction is permitted which does not comply with these terms. 